\title{
VI ВСЕРОССИЙСКАЯ КОНФЕРЕНЦИЯ С МЕЖДУНАРОДНЫМ УЧАСТИЕМ «НОВЫЕ ДОСТИЖЕНИЯ В ХИМИИ И ХИМИЧЕСКОЙ ТЕХНОЛОГИИ РАСТИТЕЛЬНОГО СЫРЬЯ»
}

VI Всероссийская конференция с международным участием «Новые достижения в химии и химической технологии растительного сырья» состоялась 22-24 апреля 2014 г. в Барнауле, в Алтайском государственном университете.

В работе конференции приняли участие более 200 человек, из них около 100 ученых из 13 городов России и ближнего зарубежья (Барнаул, Новосибирск, Красноярск, Москва, Бийск, Санкт-Петербург, Архангельск, Сыктывкар, Томск, Владивосток, Сургут, Нижний Новгород, Караганда), - представители 41 научной и научно-производственной организаций. Авторами 229 материалов, опубликованных в сборнике материалов конференции, являются более 520 ученых, работающих в 118 организациях из 12 стран (Армения, Беларусь, Болгария, Вьетнам, Грузия, Казахстан, Латвия, Россия, Узбекистан, Украина, Финляндия, Франция). Материалы, опубликованные в сборнике, распределены между направлениями работы конференции следующим образом: 50 - посвящены строению и свойствам основных компонентов и тканей в процессах химической переработки растительного сырья; 118 - в разделе «Состав, строение, физикохимические и медико-биологические свойства экстрактивных веществ, выделенных из растительного сырья»; 43 - «Усовершенствование действующих и создание новых технологий химической переработки растительных материалов. Химия и технология целлюлозы и бумаги»; 18 - «Высокоэффективная переработка древесного и другого целлюлозосодержащего сырья методами биотехнологии».

На конференции прочитано и обсуждено 11 пленарных докладов. Работало три секции, проведено заседание круглого стола. На секции «Строение и свойства основных компонентов и тканей в процессах химической переработки растительного сырья» заслушано 19 докладов, на секции «Низкомолекулярные компоненты растительного сырья: строение, свойства, химическое модифицирование, технологии получения, БАВ» - 26 докладов; на секции «Усовершенствование действующих и создание новых технологий химической переработки растительных материалов. Химия и технология целлюлозы и бумаги. Высокоэффективная переработка древесного и другого целлюлозосодержащего сырья методами биотехнологии» 14. Проведена стендовая сессия.

Научный анализ докладов, представленных на устных и стендовых секциях конференции, свидетельствует о значительной активизации исследований ученых в области низкомолекулярных природных соединений из растительного сырья, направленных на получение (выделение или/и синтез) различных биологически активных соединений для здоровья и красоты человека. Следует отметить усиление активности научных исследований для получения новых препаратов и субстанций для фармацевтической промышленности. Так, в частности в обзорном докладе профессор Н.Ф. Салахутдинова (Новосибирский институт органической химии СО РАН, Новосибирск) рассматривается роль различных классов растительных метаболитов в создании современных противоопухолевых препаратов, как использующихся в медицине в настоящее время, так и находящихся на различных этапах доклинических и клинических испытаний. Особое внимание уделено следующим классам соединений: таксоиды, флаваноиды, тритерпеновые кислоты, фенольные соединения, алкалоиды, лактоны. Рассматриваются синтетические трансформации различных растительных метаболитов и связь «структура - активность». Профессор В.А. Бабкин (Иркутский институт химии, Иркутск) посвятил свой обзорный доклад рассмотрению теоретических основ и практических разработок новых препаратов из экстрактивных веществ биомассы лиственницы для медицины, пищевой и сельскохозяйственной промыш- 
ленности. Отдельно докладчик остановился на опыте успешной организации производства полезных веществ из древесины лиственницы (дегидрокверцетин, арабиногалактан и др.).

В пленарном докладе профессора Э.Х. Ботирова (Сургутский государственный университет Сургут) приведены последние результаты по фитохимическому изучению флавоноидов и кумаринов растений семейств рутовых, бобовых и хвощевых и перспективам использования данных растений в качестве источника биологически активных веществ.

Доклады профессоров О.И. Ломовского, А.В. Душкина, канд. хим. наук А.Л. Бычкова (Институт химии твердого тела и механохимии СО РАН, Новосибирск) посвящены использованию механохимических методов при синтезе новых лекарственных веществ на основе природных соединений и выделении индивидуальных органических соединений или их групп их природного растительного сырья. Показаны их высокая эффективность и перспективы промышленного использования данных методов в фармацевтической промышленности с точки зрения зеленой химии.

В пленарном сообщении профессора Б.Н. Кузнецова (Институт химии и химической технологии CO РАН, Красноярск) показана роль гетерогенно-каталитических процессов получения ценных химических продуктов и биотоплив из лигноцеллюлозной биомассы. Предложены новые технологические решения, которые могут быть реализованы в промышленных масштабах.

В докладах профессора А.Ф. Гоготова (Иркутский институт химии, Иркутск) и канд. хим. наук И.С. Ильичева (Биохимический холдинг «Оргхим», Нижний Новгород) рассказаны современные промышленные технологии и технические решения, которые позволяют с высокой эффективностью перерабатывать растительное сырье в широкую гамму полезных продуктов, которые применяются в различных областях жизнедеятельности человека.

Анализ работы секций «Строение и свойства основных компонентов и тканей в процессах химической переработки растительного сырья» и «Усовершенствование действующих и создание новых технологий химической переработки растительных материалов. Химия и технология целлюлозы и бумаги. Высокоэффективная переработка древесного и другого целлюлозосодержащего сырья методами биотехнологии» (и материалов докладов сборника конференции) показал, что современные исследования в области переработки древесины и однолетнего растительного сырья нацелены на использование биотехнологических методов. В частности это связано и с проблемой получения дешевого биотоплива из растительного сырья, которой уделяется в настоящее время большое внимание. Ряд докладов посвящены проблеме исследования процессов химического модифицирования растительного сырья без предварительного разделения на отдельные компоненты в ценные продукты. Впервые представлены перспективные результаты получения микрокристаллической целлюлозы и ее простых эфиров непосредственно из химически модифицированной древесины. Продолжаются исследования по совершенствованию технологий делигнификации различных видов растительного сырья с целью получения целлюлозы разных марок, а также получению из нее бумаги. Работы в данных направлениях продолжаются во многих крупных научных центрах Центральной России и Сибири и нацелены на крупнотоннажное производство. Российские научные школы в данных направлениях являются одними из ведущих в мире. В данной области получен ряд существенных результатов. Эти разработки пока не нашли практического воплощения, хотя к ним проявляют интерес конечные потребители. Исследования в данной области тормозятся необходимостью вливания значительных финансовых ресурсов как в исследовательскую базу научных центров, так и в технологическую, которые позволили бы изменить/внедрить новые технологии. Кроме того, необходимы промышленные испытания, апробация и внедрение в промышленное производство.

Как показывает анализ докладов, представленных на секции «Низкомолекулярные компоненты растительного сырья: строение, свойства, химическое модифицирование, технологии получения, БАВ» (и материалов докладов сборника конференции), наиболее интенсивно проводящиеся исследования в области химии и химической технологии растительного сырья проводятся именно в этом направлении. Это связано прежде всего с поддержкой подобных исследований различными фондами, улучшением материальнотехнической базы, которая позволяет проводить такие работы. Именно к подобным работам проявляет интерес малый и средний бизнес. Капиталовложения в эти исследования относительно невелики, а возможная прибыль и окупаемость вложений значительны. На конференции представлены результаты научных исследований, которые получили практическое воплощение в ряде товарных продуктов (масла для тела различного назначения, эфирные масла для ароматерапии, БАДы, основа для изготовления фармпрепаратов и др.) 
На базе ЗАО «Алтайвитамины» (Бийск) проведен круглый стол «Проблемы внедрения научных разработок в производство», в котором приняло участие более 60 человек - ученые, представители бизнеса, а также представители администрации Алтайского края. Заслушаны сообщения в области инновационных фармацевтических технологий и обсуждены насущные проблемы внедрения научных разработок в фармацевтическое производство. Высказаны предложения по взаимодействию науки и бизнеса в целом через биофармацевтические кластеры. Выступавшие представители ЗАО «Алтайвитамины» и других малых и средних предприятий Алтайского края, Томской и Иркутской областей отмечали актуальность проводимой конференции и заинтересованность в активизации научных исследований, нацеленных на получение новых продуктов для фармацевтической промышленности на основе растительного сырья.

В ходе конференции обсужден большой комплекс вопросов, связанных как с научными подходами к переработке растительного сырья, так и с их практическим воплощением. С удовлетворением можно констатировать, что исследования в данной области проводятся довольно активно, и их уровень соответствует общемировому, а в некоторых областях даже его превышает. Однако уровень финансовой поддержки этих исследований оставляет желать лучшего. Многие исследования проводятся на инициативной основе. Лишь около $10 \%$ работ, опубликованных в сборнике докладов конференции, поддержаны теми или иными финансовыми организациями (в том числе РФФИ). Чтобы не отстать от зарубежных исследователей, работающих в данной области, необходима дополнительная финансовая поддержка.

\section{Решения конференции}

1. Считать Всероссийскую научную конференцию с международным участием «Новые достижения в химии и химической технологии растительного сырья» научно-практической информационной платформой, являющейся существенной частью для развития технологического рынка в области переработки растительного сырья.

2. Отметить системообразующую роль журнала «Химия растительного сырья» в информационной и методической поддержке научного сообщества в области переработки растительного сырья и программной подготовке конференции.

3. Акцентировать внимание ученых на исследовании биотехнологических способов переработки растительного сырья.

4. Направить информацию о результатах VI Всероссийской научной конференции с международным участием «Новые достижения в химии и химической технологии растительного сырья» в Департамент химико-технологической и лесоперерабатывающей промышленности, Департамент фармацевтической и медицинской промышленности Министерства промышленности и торговли РФ, технологическую платформу «Биоиндустрия и биоресурсы БиоТех 2030».

5. Информацию об итогах конференции разместить в журнале «Химия растительного сырья».

6. Организовать в 2017 г. проведение VII Всероссийской научной конференции с международным участием «Новые достижения в химии и химической технологии растительного сырья» в г. Барнауле на базе ФГБОУ ВПО «Алтайский государственный университет».

Оргкомитет выражает благодарность Российскому фонду фундаментальных исследований, биохимическому холдингу «Оргхим», фармацевтической компании «Алтайвитамины», ООО «Реолгрейдс сервис», ЗАО «Шаг» за финансовую и материально-техническую поддержку при проведении конференции.

Председатель оргкомитета Н.Г. Базарнова

Ответственный секретарь В.И. Маркин 
